\title{
What is in Store for 2019 in Stem Cell Reviews and Reports
}

\author{
Mariusz Z. Ratajczak ${ }^{1}$ \\ Published online: 26 December 2018 \\ (C) The Author(s) 2018
}

We enter the new year of 2019 of SCRR under new leadership. We are pleased to thank the excellent work of our Section Editors, Editorial Board members, and dedicated reviewers. We accepted the best papers, and our impact factor increased to 3.612. Stem Cell Reviews and Reports covers a broad range of topics, including different aspects of stem cell biology and tissue/organ regeneration.

Our journal is open not only to clear scientific progress, but also to new and challenging ideas as well as some controversies in the field - following a famous quote of Albert Einstein who used to say that "A blind belief in authority is the worst enemy of truth" and a famous saying from Max Planck" One rule is important in science - only courageous people win". Therefore, we encourage you to submit your best work and help establish our journal as the premier journal in this important field.

Taking into consideration the increasing number of submitted papers to SCRR, with this new year 2019 we are pleased to announce the recruitment of two new Section Editors. The first one, Prof. Tiziana Brevini from the University of Milan, Italy, will help to evaluate papers related to regenerative medicine, and the second one, Prof. Zbigniew Darzynkiewicz from New York College of Medicine, USA, who will be responsible for a section on cancerogenesis and stem cells in aging. They will work together with our other four respected section editors Drs. Giovanni Camussi, Henning Ulrich, Louis Pelus and Edward Scott to bring our journal to the next level of excellence. Our current acceptance rate is $\sim 28 \%$.

We also welcome 6 new Editorial Board members Drs. Alexander Birbrair from the Federal University of Minas Gerais, Brazil, Cesario Borlongan from the University of South Florida, USA, Nadim Mahumd from the University of Illinois

Mariusz Z. Ratajczak

mariusz.ratajczak@louisville.edu

1 University of Louisville, Louisville, KY, USA
College of Medicine, USA, Krzysztof Marycz from Justus Liebig University Giessen, Germany, and Environmental and Life Science University Wroclaw, Poland, and Yuzhen Tan, from Fudan University, Shanghai, China, who will replace a few Editorial Board members who will step back after serving for a 2 year term of appointment.

We are living in very exciting times of stem cell research and their potential application in the clinic. Hematopoietic stem cells (HSC) have been successfully employed for 60 years in hematological transplantations. The successful clinical application of monopotent HSCs is widely understood to have helped establish the rationale for the development of stem cell therapies and regenerative medicine. Therefore, widely understood regenerative medicine is looking for a pluripotent/multipotent stem cell able to differentiate across germ layers and be safely employed in therapy. Unfortunately, with the exception of HSC for hematological applications, the current clinical results with adult stem cells are somewhat disappointing. Clinical effects with mesenchymal stem cells in regeneration of damaged organs are related to soluble factors and macrovesicles secreted by these cells. Furthermore, the potential clinical applications of the more primitive induced pluripotent stem cells (iPSCs) have so far been discouraging, as both have exhibited several problems, including genomic instability, a risk of teratoma formation, and the possibility of rejection. Moreover, the current results for clinical applications of iPSCs in patients have demonstrated only paracrine effects in therapy and no contribution of these cells to damaged organs. This all suggests a risk of an approaching twilight for the clinical application of iPSCs, unless some strategies will be developed to avoid these limitations. Therefore, more work is needed in this promising area. We need to better understand the molecular mechanisms involved in regulating stem cell pluripotency and differentiation. Evidence indicates that non-coding mRNA and miRNA are substantial components of regulatory networks in early development stem cells. We also need to find out if adult tissues contain some very rare early development 
stem cells - postulated since many years by several investigators.

Going forward, Stem Cell Reviews and Reports will continue to publish the latest discoveries and to entertain challenging and provocative ideas. As I mentioned above we encourage you to submit your best work and help establish our journal as the premier journal in this important field.
Open Access This article is distributed under the terms of the Creative Commons Attribution 4.0 International License (http:// creativecommons.org/licenses/by/4.0/), which permits unrestricted use, distribution, and reproduction in any medium, provided you give appropriate credit to the original author(s) and the source, provide a link to the Creative Commons license, and indicate if changes were made.

Publisher's Note Springer Nature remains neutral with regard to jurisdictional claims in published maps and institutional affiliations. 